\title{
Enumeration of propionibacteria in raw milk using a new selective medium
}

\author{
A Thierry, MN Madec \\ laboratoire de recherches de technologie laitière, INRA, \\ 65, rue de Saint-Brieuc, 35042 Rennes cedex, France
}

\begin{abstract}
Summary - Propionibacteria were enumerated using a new medium in 202 raw milk samples taken from tanker lorries, collected over a 1-year period from 9 regions of France. This medium, called $\mathrm{Pal}$ Propiobac, has been compared with yeast extract lactate agar (YELA) for its efficiency to enumerate propionibacteria in 29 of these milk samples. Propionibacteria counts were of the same order of magnitude on both media. However, total counts on YELA (reflecting all the milk flora able to grow on the medium) were markedly higher than total counts on Pal Propiobac, which shows a higher selectivity of the latter medium towards milk microorganisms other than propionibacteria. Moreover, more than onequarter ( 8 of 29) of the milk samples could not have been enumerated on YELA because of the lack of colonies of typical appearance on this medium. Propionibacteria counts in raw milk ranged between less than $10 \mathrm{cfu} / \mathrm{ml}$ to $1.310^{4} \mathrm{cfu} / \mathrm{ml}$. The variations observed for milk samples collected the same day in a given region were of the same order of magnitude as variations depending on regional or seasonal factors. The geometric mean of propionibacteria counts of all the tested samples was $2.19 \mathrm{log} \mathrm{cfu} / \mathrm{ml}$, with a standard deviation of 0.58 . The significance of the propionibacteria content of milk for cheese technology is discussed.
\end{abstract}

propionic acid bacteria / raw milk / selective medium / enumeration

Résumé - Dénombrement des bactéries propioniques du lait cru au moyen d'un nouveau milieu sélectif. Le dénombrement des bactéries propioniques de 202 échantillons de lait cru provenant de citernes de collecte, prélevés dans 9 régions de France au cours d'une année, a été effectué grâce à un nouveau milieu. Ce milieu, commercialisé sous le nom Pal Propiobac, a été évalué comparativement au milieu YELA (yeast extract-lactate-agar) pour dénombrer les bactéries propioniques de 29 échantillons de lait. La flore propionique a été dénombrée à un niveau équivalent sur les 2 milieux. La flore totale capable de se développer sur YELA a été en revanche nettement supérieure à la flore totale poussant sur $\mathrm{Pal}$ Propiobac, ce qui démontre une sélectivité supérieure de ce dernier milieu vis-à-vis de la flore non propionique du lait. De plus, plus d'un quart des échantillons (8 sur 29) n'ont pu être dénombrés sur YELA du fait de l'absence de colonies typiques sur ce milieu. La flore propionique des échantillons de lait cru a varié entre moins de $10 \mathrm{ufc} / \mathrm{ml}$ et 1,3104 ufc/ml. Les variations observées pour des échantillons collectés le même jour dans une région donnée ont été du même ordre de grandeur que les variations existant d'une région à l'autre ou d'une saison à l'autre. La moyenne géométrique des dénombrements effectués s'élève à 2,19 log ufc/ml, avec un écart type de 0,58 log $u f c / m l$. La signification en technologie fromagère du niveau de la flore propionique du lait est discutée. 


\section{INTRODUCTION}

Propionibacteria have long been known as essential for the development of the characteristic flavour and eye formation in Swissand related-type cheeses (Sherman, 1921). Originally present in milk, they essentially grow during warm room ripening $\left(18-24^{\circ} \mathrm{C}\right)$ and reach $10^{9} \mathrm{cfu}$ (colony forming units) per gram of cheese at 4-8 weeks (Chapman and Sharpe, 1981), fermenting the lactate produced by the thermophilic lactic bacteria into propionic and acetic acids and $\mathrm{CO}_{2}$ (Langsrud and Reinbold, 1973). Their development may also result in defects in cheese varieties where propionic fermentation is not desirable (Champagne and Lange, 1990; Carcano et al, 1993).

During the past several years, the need for better knowledge of propionibacteria in milk and of their development in cheese has been emphasized by cheesemakers. Unfortunately, very few data are available concerning propionic flora in milk. The presence of propionibacteria in milk may result from contamination by soil or silage where they have been found (Cummins and Johnson, 1986), but no work has been done regarding their definite origin. Concerning propionibacteria counts in milk, studies of Forster et al (1987) and Carcano et al (1993), using lactate agar media, reported a high variation of propionibacteria counts in Swiss and Italian milks. To our knowledge, no results have been published concerning propionibacteria content in French milks although France produces more than 240000 tonnes of Swiss-type cheese per year (SIGF, 1994).

This lack of data may be due to the absence of an effective selective medium for enumeration of propionibacteria. The yeast extract sodium lactate agar (YELA) of Malik et al (1968), or similar media based on the ability of propionibacteria to ferment lactate and grow anaerobically, are usually used for the enumeration of propionibacteria (Holzapfel, 1992). However, their selec- tivity is not high enough to allow an easy enumeration of propionibacteria in media as complex as milk: many starter and nonstarter bacteria are able to grow on these media (Britz and Holzapfel, 1973; Drinan and Cogan, 1992; Thierry et al, 1994).

Several attempts have been made to increase the selectivity of lactate agar media by using inhibitory compounds (Kurmann,1962; Britz and Holzapfel, 1973; Peberdy and Fryer, 1976; Tomes et al, 1991; Drinan and Cogan, 1992) without satisfactory selectivity towards milk or cheese flora. More recently, Madec et al (1994) developed a new medium containing glycerol in combination with lithium and antibiotics, which differenciates glycerol-fermenting microorganisms and is suitable for enumerating propionibacteria in cheese and milk.

The aim of the present investigation was to determine propionibacteria counts using this new patented medium (commercialized as "Pal Propiobac") in raw milk samples collected from tanker lorries in several regions of France at different periods of the year.

\section{MATERIALS AND METHODS}

\section{Milk sampling}

Milk was sampled over a 1-year period from 9 regions of France. Each milk sample was taken from a tanker lorry, representative of 5 to 20 milk producers. Samples were kept between 4 and $10^{\circ} \mathrm{C}$ for $36 \mathrm{~h}$ before analysis in order to prevent bacterial development during transportation.

\section{Enumeration of propionic flora}

The medium used was patented by Madec et al (1994) and now available from Standa-Industrie (Caen, France) under the brand name Pal Propiobac ${ }^{(}$. This medium, referred to herein as "Propiobac", was prepared with tryptone (peptone 
pancréatique de caséine plus; Organotechnie, La Courneuve, France) and yeast extract from Bio Springer (Maisons-Alfort, France). A comparison has been made with the enumeration on YELA medium containing: $1.0 \%$ tryptone (ref 19544 Biokar, Beauvais, France), $1.0 \%$ yeast extract (Biokar), 1.5\% agar type $\mathrm{E}$ (Biokar), $0.025 \% \mathrm{~K}_{2} \mathrm{HPO}_{4}, 0.005 \% \mathrm{MnSO}_{4}$ and $2.1 \%$ sodium lactate (60\% syrup) (Sigma, St Quentin Fallavier, France). The $\mathrm{pH}$ of both media was adjusted to 7.0 before sterilization $\left(121^{\circ} \mathrm{C}, 15\right.$ $\mathrm{min})$. Petri dishes were incubated in anaerobic jars (with Anaerocult A, Merck, Nogent sur Marne, France) for $6 \mathrm{~d}$ at $30^{\circ} \mathrm{C}$.

Brown colonies larger than $1 \mathrm{~mm}$ in diameter were enumerated as propionibacteria colonies on YELA. Propionibacteria enumeration was realized on Propiobac by counting colonies appearing on this medium as brown colonies larger than $0.5 \mathrm{~mm}$ in diameter, surrounded by a yellow area caused by the $\mathrm{pH}$ decrease resulting from glycerol fermentation by propionic acid bacteria.

\section{Confirmatory tests}

Some typical or less typical colonies were picked up and purified. Liquid subcultures of presumptive propionibacteria were then tested for their ability to produce propionic and acetic acids from lactate on YEL (YELA without agar). Acids were measured by high performance liquid chromatography (HPLC) using an ion-exchange column (7.5 X $300 \mathrm{~mm}$; Aminex A6, Biorad, Richmond, VA, USA) operated at ambiant temperature with $\mathrm{H}_{2} \mathrm{SO}_{4} 0.01 \mathrm{~N}(1 \mathrm{ml} / \mathrm{min})$ as eluent. Further confirmation was carried out when necessary by checking erythritol fermentation (Cummins and Johnson, 1986). Nonpropionibacteria strains isolated on selective media were tested for simple characterization (catalase test, microscopical examination), and further testing was done if necessary.

\section{Comparison of YELA and Propiobac media selectivity}

Two distinct counts were made on both selective media: propionibacteria counts, as described earlier, and total counts (except "pin point" colonies), which reflect all the milk flora able to grow on the medium. These total counts were used as selectivity indicators towards milk flora: the less selective the medium, the higher the total counts.

\section{Standard plate counts}

In addition, total mesophilic flora was enumerated for some milk samples on PCA (Plate Count Agar Biokar, Beauvais, France) to research a possible relationship between the bacteriological quality of tested milk and its propionibacteria content. Plates were incubated aerobically at $30^{\circ} \mathrm{C}$ for $3 \mathrm{~d}$.

\section{RESULTS AND DISCUSSION}

\section{Comparison between Propiobac and YELA for enumeration of propionibacteria in milk}

Comparative enumeration was carried out using YELA and Propiobac on 29 milk samples coming from 3 different regions of France during the end of spring or beginning of summer. In addition, standard plate counts were made on PCA for the samples from the Ille-et-Vilaine region. Figure 1 illustrates the relationship between propionibacteria counts and total counts on PCA, YELA and Propiobac for 10 of these samples, chosen among those having the highest and the lowest counts on PCA. The results are given in full in table $\mathrm{I}$.

\section{Total counts}

As shown in table I, the differences between the total counts on Propiobac and YELA, expressed in log units, ranged from 0.7 to 3.8, depending on the samples. These results demonstrate the low selectivity of YELA towards milk flora and are in agreement with the observations of several authors (Britz and Holzapfel, 1973; Drinan and Cogan, 1992). 
Total counts on YELA were tentatively correlated with counts on PCA. A linear relationship was shown between total counts on YELA and standard plate counts $(P<$ 0.01 ), with the following regression equa- tion: $(\log \mathrm{cfu} / \mathrm{ml}$ on YELA $)=(\log \mathrm{cfu} / \mathrm{ml}$ on PCA) $\times 1.0152-0.7838, r^{2}=0.92, n=29$ ). In other words, total counts on YELA were about 6 times lower than on PCA whatever the microbiological content of milk samples.

Table I. Comparison between total counts and propionibacteria counts on PCA, YELA and Pal Propiobac media in raw milk samples taken from tanker lorries.

Comparaison des flores totales et propioniques dénombrées sur les milieux PCA, YELA et Pal Propiobac dans des échantillons de lait cru provenant de citernes de collecte.

Milk samples

origin

\begin{tabular}{|c|c|c|c|c|c|}
\hline \multirow{3}{*}{ IgIr } & & & & & \\
\hline & \multicolumn{3}{|c|}{ Total count } & \multicolumn{2}{|c|}{ Propionibacteria count } \\
\hline & $P C A$ & YELA & Propiobac & YELA & Propiobac \\
\hline \multirow[t]{21}{*}{ Ile-et-Vilaine } & 7.14 & 6.90 & 3.11 & 2.78 & 2.90 \\
\hline & 7.08 & 6.19 & 2.62 & 2.86 & 2.62 \\
\hline & 6.45 & 5.61 & 3.00 & 3.00 & 3.00 \\
\hline & 6.12 & 5.45 & 2.70 & 2.64 & 2.70 \\
\hline & 5.8 & 4.85 & 2.92 & 2.92 & 2.92 \\
\hline & 5.73 & 5.52 & 2.96 & 3.07 & 2.73 \\
\hline & 5.01 & 4.61 & 3.45 & nc & 3.45 \\
\hline & 5.2 & 3.90 & 2.53 & 2.56 & 2.53 \\
\hline & 4.41 & 3.70 & 2.50 & 2.15 & 2.30 \\
\hline & 4.36 & 3.80 & 2.80 & 3.20 & 2.80 \\
\hline & 4.48 & 3.90 & 2.50 & nc & 2.30 \\
\hline & 4.58 & 3.45 & 2.36 & 2.30 & 1.90 \\
\hline & 4.15 & 3.60 & 2.59 & 2.20 & 2.51 \\
\hline & 4.38 & 4.05 & 1.90 & 1.30 & 1.90 \\
\hline & 4.46 & 3.60 & 2.60 & 2.51 & 2.60 \\
\hline & 4.6 & 4.04 & 2.83 & 2.00 & 2.73 \\
\hline & 4.3 & 3.10 & 2.40 & 2.26 & 2.20 \\
\hline & 4.15 & 3.70 & 2.08 & nc & 1.90 \\
\hline & 4.51 & 3.30 & 1.10 & nc & 1.00 \\
\hline & 3.65 & 3.10 & 1.80 & 2.00 & 1.73 \\
\hline & 3.49 & 2.80 & 0.70 & $0.5 ?$ & 0.60 \\
\hline \multirow[t]{4}{*}{ Savoie } & nd & 4.40 & 2.40 & 1.20 & 1.90 \\
\hline & nd & 3.52 & 2.20 & 1.30 & 0.70 \\
\hline & nd & 4.30 & 3.11 & nc & 0.70 \\
\hline & nd & 4.00 & 3.20 & nc & 1.50 \\
\hline \multirow[t]{4}{*}{ Pas-de-Calais } & nd & 3.90 & 2.78 & 2.38 & 2.15 \\
\hline & nd & 4.85 & 3.08 & $2.58 ?$ & 2.79 \\
\hline & nd & 4.00 & 2.70 & 2.52 & 2.50 \\
\hline & nd & 4.00 & 2.85 & 1.30 & 1.78 \\
\hline
\end{tabular}

? uncertain value, valeur incertaine; nc: not countable (absence of typical colonies) non dénombrable (absence de colonies typiques); nd: not determined, non déterminé. 


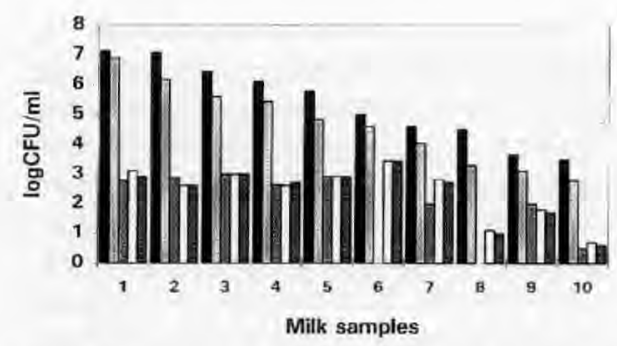

Fig 1. Enumeration of flora in 10 raw milk samples taken from tanker lorries: total counts on media: (E) PCA; (圂) YELA; ( $\mathbb{Q}$ ) Pal Propiobac; propionibacteria counts on media: (․ㅠ) YELA ; ( $\square$ ) Pal Propiobac.

Dénombrement de la flore de 10 échantillons de lait cru provenant de citernes de collecte: flore totale dénombrable sur les milieux: ( 1 ) PCA; (包) YELA; ( Pal Propiobac; flore propionique dénombrable sur les milieux: ( $\square$ ) YELA; (画) Pal Propiobac.

These surprisingly high counts of microorganisms able to grow on YELA have received little attention, because YELA or other lactate agar media are generally used as elective media on which only typical colonies of propionibacteria are counted. The YELA-growing flora probably belongs to facultative anaerobic microorganisms, such as lactic acid bacteria and enterobacteria, which constitute the main flora of low bacteriological quality milks (Richard, 1983).

\section{Propionibacteria counts}

Accurate comparison between propionibacteria counts on YELA and on Propiobac could not be made because colonies were generally enumerated on plates corresponding to 10 -fold diluted samples, where there were often fewer than 30 per plate. If nondiluted milk samples were used, the components of the milk affected the selectivity of YELA and Propiobac, resulting in a lack of typical colonies. Moreover, enumeration of propionibacteria was not possible on YELA plates for more than one-quarter ( 8 of 29) of the analysed samples because of the absence of typical colonies. When propionibacteria were detectable on YELA, however, counts on both media were of the same order of magnitude: propionibacteria counts on YELA, expressed as $\mathrm{cfu} / \mathrm{ml}$, were generally 3 times lower or higher than counts on Propiobac.

The propionibacteria counts, ranging between 0.7 and more than $3.0 \mathrm{log} \mathrm{cfu} / \mathrm{ml}$, were highly variable depending on the enumerated sample. A correlation $(P<0.01)$ was found between propionic flora and mesophilic aerobic flora, but propionibacteria count variations could not be fully explained by total bacterial content variations $\left(r^{2}=0.35\right)$.

Propionibacteria represented, on average, $65 \%$ of the total microorganisms able to grow on Propiobac and only $4 \%$ of the total flora growing on YELA. This reduction of total flora on Propiobac confirmed the higher selectivity of this medium compared to YELA. For both media, however, this ratio was highly dependent on the milk sample, reaching values as high as $100 \%$ on Propiobac for milk samples from Ille-et -Vilaine. while it decreased to $0.4-3 \%$ for 3 samples from the Savoie. For these latter samples, numerous salt-resistant cocci (presumptive enterococci) have been identified among microorganims able to grow on Propiobac. Their presence is not surprising as enterococci are well known for being resistant to numerous inhibitor compounds. Such a flora is probably responsible for a lack of selectivity of Propiobac in some cases.

Although growth of nonpropionic bacteria occurred on Propiobac, it can be considered as a selective medium according to the definition given by Reuter (1985). The reduction of nonpropionic flora and the improvement of propionibacteria detection rendered Propiobac more convenient than YELA to enumerate propionibacteria in raw milk. 


\section{Propionibacteria counts in milk and technological significance}

The results of propionibacteria enumeration on Propiobac made on 202 milk samples collected from 9 regions of France at different periods of the year are shown in table II.

Propionibacteria counts varied from less than $10 \mathrm{cfu} / \mathrm{ml}$ to more than $10^{4} \mathrm{cfu} / \mathrm{ml}$. This wide variation was found even for samples collected the same day in a given region and was of the same order of magnitude as the one observed between samples from the same region collected at different periods of the year or samples collected at the same period from different regions. This result does not allow us to draw any conclusion about the influence of seasonal or regional factors on propionibacteria concentration in milk.
However, in milk from the Savoie collected at 3 different periods of the year, propionibacteria counts were lower than in other regions. This result could not be fully explained. For many samples, no growth occurred on Propiobac (neither propionibacteria nor adventicious flora). However, some samples from the Savoie contained a nonpropionic flora able to grow on Propiobac. The growth of large numbers of adventicious microorganisms may have resulted in the inhibition of propionibacteria growth, leading to a low propionibacteria count in these samples. Further experiments were carried out to verify this hypothesis by enumerating milk samples after adding to such milk samples propionibacteria starters at a known count: the results obtained (data not shown) showed the adventicious flora delayed propionic flora growth, resulting in the lack of typical colonies after $6 \mathrm{~d}$ of incubation.

Table II. Enumeration of propionibacteria using Pal Propiobac medium in 202 raw milk samples taken from tanker lorries.

Dénombrement des bactéries propioniques avec le milieu Pal Propiobac pour 202 échantillons de lait cru provenant de citernes de collecte.

\begin{tabular}{lcccc} 
Milk origin & $\begin{array}{c}\text { Sampling } \\
\text { month }\end{array}$ & $\begin{array}{c}\text { No of } \\
\text { samples }\end{array}$ & $\begin{array}{c}\text { Propionibacteria count (cfu/ml of milk) } \\
\text { Geometric mean }\end{array}$ & Range of counts \\
\hline $\begin{array}{l}\text { Ile-et-Vilaine } \\
\text { lle-et-Vilaine }\end{array}$ & 07 & 23 & 240 & $<10-2800$ \\
Savoie & 11 & 29 & 182 & $<10-13000$ \\
Savoie & 02 & 15 & 22 & $<10-600$ \\
Savoie & 05 & 10 & 25 & $<10-120$ \\
Cantal & 07 & 6 & 24 & $<10-60$ \\
Cantal & 04 & 15 & 355 & $90-1060$ \\
& 05 & 17 & 275 & $120-780$ \\
Finistère & 12 & 10 & 190 & $120-1200$ \\
Vosges & 12 & 20 & 186 & $40-2400$ \\
Mayenne & 12 & 20 & 141 & $20-1200$ \\
Ain & 03 & 5 & 83 & $40-200$ \\
Jura & 03 & 13 & 150 & $70-350$ \\
Pas-de-Calais & 05 & 19 & 407 & $60-2200$ \\
Total & - & 202 & 157 & $<10-13000$ \\
& & & &
\end{tabular}


Figure 2 shows the distribution of samples as a function of their propionibacteria count. Despite the wide variations observed, two-thirds of the samples had propionibacteria counts ranging between 60 and 540 $\mathrm{cfu} / \mathrm{ml}$. Assuming that propionibacteria were present at $5 \mathrm{cfu} / \mathrm{ml}$ when they could not be enumerated (counts lower than $10 \mathrm{cfu} / \mathrm{ml}$ ), geometric means of propionibacteria counts were calculated for each group of samples (samples from a given region collected at the same period). The highest mean value was 18 times higher than the lowest mean value. The mean of the propionibacteria counts of the totality of the tested samples, expressed as log cfu/ml, was equal to 2.19, with a standard deviation of 0.58 .

The propionibacteria content of milk is not well-documented. Demeter found in 1953 about $210^{3} \mathrm{cfu} / \mathrm{ml}$ of cheese-milk. In their review, Choisy et al (1987) report that propionibacteria are present at $104 / \mathrm{g}$ of young Emmental cheese before its ripening in warm room. Propionibacteria count in curd depends on their content in milk, but also on the decrease in count that occurs during curd "cooking" and on the increase in count due to their concentration in curd. Propionibacteria achieve a reduction in count ranging between 0.3 and $4 \log$ units (Guezenec, personal communication). The physical entrapment of several bacteria in curd results in an about 10-fold increase in

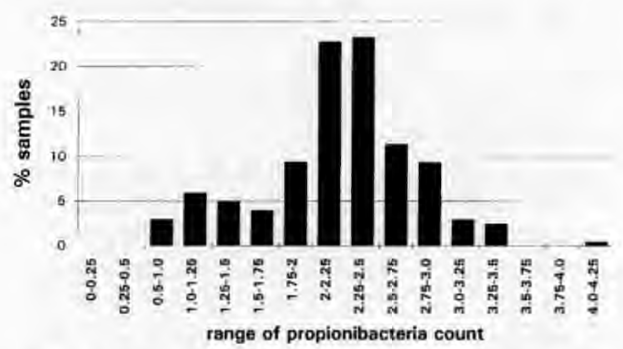

Fig 2. Distribution of 202 milk samples as a function of their propionibacteria count.

Distribution de 202 échantillons de lait cru en fonction de leur teneur en bactéries propioniques. count (Tatini et al, 1971; Accolas et al, 1978). Assuming that propionic flora decreases 10 times during cooking and is then concentrated 10 times in curd, the value given by Choisy and co-workers would be reached with a milk containing $10^{4}$ propionibacteria per $\mathrm{ml}$. Such high counts have only very rarely been found in our study.

Our results are consistent, however, with recent Swiss and Italian studies. Using a YELA-type medium, Forster et al (1987) studied the bacteriological quality of raw milk used for Emmental cheesemaking. They reported propionibacteria counts between 5 and $1600 \mathrm{cfu} / \mathrm{ml}$ in raw milk, with an average value (geometric mean) of 10 $\mathrm{cfu} / \mathrm{ml}$. They did not find any influence of the type of fodder used for cow feeding on propionibacteria content in milk. Using a YELA-type medium, Carcano et al (1993) analysed the presence of propionibacteria in 274 samples of milk delivered over a 1-year period to 2 cheese factories and used for Grana cheesemaking. All samples contained propionibacteria, at counts ranging from 10 to $2.710^{4} \mathrm{cfu} / \mathrm{ml}$. Large variations in count have also been observed in raw milk for other microorganisms such as Lactobacillus and Leuconostoc (Desmasures et al, 1994).

The development of propionibacteria in cheese depends not only on the propionibacteria content of milk, but also on technological factors whose influence has been comprehensively reviewed (Langsrud and Reinbold, 1973; Bergère and Accolas, 1986). Nevertheless, the initial propionibacteria count is of great importance in the technology of cheeses, whether or not propionic fermentation is desirable.

Although in most cheesemaking technologies, propionibacteria have no known role and are harmless, they have been cited as a potential cause of defects in several cases: late blowing in Grana cheesemaking (Carcano et al, 1993), abnormal gas formation in Mozzarella cheese (Champagne 
and Lange, 1990). However, appreciable numbers of propionibacteria have also been found in normal Grana cheese, but their impact remains undetermined (Thompson and Marth, 1986). Equally in Swiss-type cheese, uncontrolled propionic fermentation due to milk indigenous flora can lead to cheese defects: the split defect, for example, is caused by secondary fermentation during Gruyere and Emmental cheese ripening (Forster et al, 1987; Pauchard, 1993).

These defects can be observed even with initial counts as low as those found in our study. Pauchard (1993) reported that milk must contain less than 50 propionibacteria cfu/ml to be convenient for Gruyere cheesemaking. He showed that inoculation of only 200 propionibacteria per $\mathrm{ml}$ of cheese milk resulted in split defects during Gruyere ripening. These results are not surprising when we take into account the ripening conditions in Swiss-type cheese technology. Propionibacteria grew during ripening at $24^{\circ} \mathrm{C}$ with a generation time between 18 and $26 \mathrm{~h}$ (Thierry et al, 1994). Assuming these values and an initial propionic count as low as $200 \mathrm{cfu} / \mathrm{g}$ of cheese at the beginning of warm room, propionic flora would theoretically reach $510^{9} \mathrm{cfu} / \mathrm{ml}$ in less than 4 weeks.

Excessively low propionibacteria counts can also result in defects, as demonstrated by Baer et al (1993). Investigating the origin of "brown spots" in Emmental cheese, the authors showed that this defect appears in 24-h cheese containing less than 500 propionibacteria cfu/g. This phenomenon is observed whatever the strains used for inoculation. They suggest that each brown spot is a single colony, as shown a century ago by Burry (1898) and Thöni and Alleman (1910).

These studies highlight the necessity of controlling propionibacteria of milk and of using appropriate propionibacteria starters. Propionibacteria inoculation is generally made at counts ranging between $5.10^{2}$ and
$5.10^{4} \mathrm{cfu} / \mathrm{ml}$ (Reinbold, 1972), but the lack of data on the development of propionibacteria (indigenous strains and starters) in cheese result in an empirical use of these bacteria.

\section{ACKNOWLEDGMENTS}

We wish to thank the following companies and laboratories for kindly providing milk samples: Alliance Agro Alimentaire, CINTERLIV, Coopérative laitière du Beaufortain, Fromagerie de l'Ermitage, Fromagerie Guilloteau, Prospérité Fermière, UNICOPA, INRA-LRF and INRASRTAL laboratories, and Standa-Industrie (Caen) for allowing us to publish these results.

\section{REFERENCES}

Accolas JP, Veaux M, Vassal L, Mocquot G (1978) Evolution de la flore lactique thermophile au cours du pressage des fromages à pâte cuite. Lait 58, 118-132

Baer A, Ryba I, Grand M (1993) Ursachen der Entstehung von braunen Tupfen im Käse. Schweiz Milchw Forschung 22, 3-7

Bergère JL, Accolas JP (1986) Non-sporing and sporing anaerobes in dairy products. In: Anaerobic bacteria in habitats other than man (EM Barnes, GC Mead, eds) Blackwell Scientific Publications, London, UK, 373-396

Britz TJ, Holzapfel WH (1973) The suitability of different media for the isolation and enumeration of propionibacteria from dairy products. S Afr J Dairy Technol $5,213-216$

Burri R (1898) Ueber das Vorkommen relativ grosser Bakterienkolonien in Fehlerhattem Emmentalerkäse. Zentralbl Bakteriol Abt [1] 4, 608-615

Carcano M, Lodi R, Todesco R, Vezzoli F (1993) I batteri propionici nel latte destinato alla produzione del formaggio Grana. Latte 18, 914-919

Champagne CP, Lange M (1990) Analyses sur fromages Mozzarella de type américain ayant montré une production anormale de gaz. Sci Aliments 10, 43-55

Chapman HR, Sharpe ME (1981) Microbiology of cheese. In: Dainy microbiology, vol 2 (RK Robinson, ed) Applied Science Publishers, London, UK, 157 243

Choisy C, Guéguen M, Lenoir J, Schmidt JL, Tourneur C (1987) Les phénomènes microbiens. In : Le fromage (A Eck, ed) Technique et documentation Lavoisier, Paris, 259-290 
Cummins CS, Johnson JL (1986) Propionibacterium. In: Bergey's manual of systematic bacteriology, vol 2 (PH Sneath, NS Mair, HE Sharpe, JG Holt, eds) The Williams \& Wilkins Co, Baltimore, MD, USA, 1346-1353

Demeter KJ, Janoschek A, Günther E (1953) Weiteres über die Bakterologie der Emmentalerkăse-Bereitung und -Reifung. Milchwissenschaft 8, 420-426

Desmasures N, Bazin F, Lejeune J, Guéguen M (1994) Evaluation de la part prise par les flores technologiquement utiles dans des laits super $A$ destinés à la transformation en fromage $A O C$ au lait cru. In: Gestion des populations microbiennes dans les industries agro-alimentaires, colloque SFM, Paris

Drinan FD, Cogan TM (1992) Detection of propionibacteria in cheese. J Dairy Res 59, 1-5

Forster I, Grand M, Glättli H (1987) Mikrobiologische Qualität der Rohmilch in verschiedenen Regionen des Schweiz. Schweiz Milchw Forschung 16, 7983

Holzapfel WH (1992) Culture media for non-sporulating Gram-positive food spoilage bacteria. Int J Food Microbiol 17, 113-133

Kurmann J (1962) Eine Metodische Verbesserung zur Bestimmung des Propionsäurebakteriengehaltes der Emmentalerkäsereimilch. XVI Int Dairy Congr C, Copenhagen, Denmark, 377-382

Langsrud T, Reinbold GW (1973) Flavor development and microbiology of Swiss cheese. A review. II. Starters, manufacturing processes and procedures. J Milk Food Technol 36, 531-542

Madec MN, Rouault A, Maubois JL, Thierry A (1994) Milieu sélectif pour le dénombrement des bactéries propioniques. Eur Patent Application PCT/FR 94000 82

Malik AC, Reinbold GW, Vedamuthu ER (1968) An evaluation of the taxonomy of Propionibacterium. Can $J$ Microbiol 14, 1185-1191
Pauchard JP (1993) La fermentation secondaire dans le Gruyère. Annual report. Federal Dairy Research Institute, Liebefeld-Bern, Switzerland, 21-23

Peberdy MF, Fryer TF (1976) Improved selective media for the enumeration of propionibacteria from cheese. NZ J Dairy Sci Technol 11, 10-15

Reinbold (1972) Traditional Swiss cheese manufacturing procedure. In: Swiss cheese varieties, vol 5 , Pfizer cheese monographs, Pfizer Inc, New York, NY, USA, 24-34

Richard J (1983) Nature de la flore microbienne dominante et sous-dominante des laits crus très pollués. Lait 63, 148-170

Reuter G (1985) Elective and selective media for lactic acid bacteria. Int J Food Microbiol 2, 55-68

Sherman JM (1921) The cause of eyes and characteristic flavor in Emmental or Swiss cheese. J Bacteriol 6, 379-392

SIGF (1994) Statistiques pâtes pressées cuites. SIGF, Paris, France

Tatini SR, Jezeski JJ, Morris HA, Olson JC, Casman EP (1971) Production of staphylococcal enterotoxin A in Cheddar and Colby cheeses. J Dairy Sci 54, 815-825

Thierry A, Madec MN, Richoux R (1994) Croissance des bactéries propioniques dans le fromage : comparaison de 2 milieux de dénombrement. Lait 74, 161-171

Thompson TL, Marth EH (1986) Changes in Parmesan cheese during ripening: microflora-coliforms, enterococci, anaerobes, propionibacteria and staphylococci. Milchwissenschaft 41, 201-205

Thöni J, Alleman O (1910) Über das Verkommen von gefärbten, makroskopischen Bakterienkolonien in Emmentalerkäsen. Zentralbl Bakteriol 25,8-31

Tomes NJ, Henderick CA, Glatz BA (1991) Selective medium for Propionibacterium growth. US Patent $n^{\circ} 5026647$ 